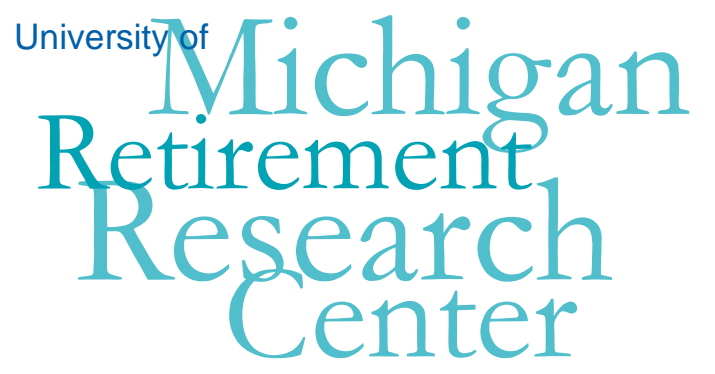

Working Paper WP 2011-252

\title{
The Influence of Public Policy on Health, Wealth and Mortality
}

\author{
John Karl Scholz and Ananth Seshadri
}

\begin{tabular}{|l|l|}
\hline $\mathrm{M}$ & $\mathrm{R}$ \\
\hline $\mathrm{R}$ & $\mathrm{C}$ \\
\hline
\end{tabular}

Project \#: UM11-12 



\title{
The Influence of Public Policy on Health, Wealth and Mortality
}

\author{
John Karl Scholz \\ University of Wisconsin \\ Ananth Seshadri \\ University of Wisconsin \\ September 2011 \\ Michigan Retirement Research Center \\ University of Michigan \\ P.O. Box 1248 \\ Ann Arbor, MI 48104 \\ http://www.mrrc.isr.umich.edu \\ (734) 615-0422
}

\section{Acknowledgements}

This work was supported by a grant from the Social Security Administration through the Michigan Retirement Research Center (Grant \# RRC08098401-03-00). The findings and conclusions expressed are solely those of the author and do not represent the views of the Social Security Administration, any agency of the Federal government, or the Michigan Retirement Research Center.

\section{Regents of the University of Michigan}

Julia Donovan Darrow, Ann Arbor; Laurence B. Deitch, Bingham Farms; Denise Ilitch, Bingham Farms; Olivia P. Maynard, Goodrich; Andrea Fischer Newman, Ann Arbor; Andrew C. Richner, Grosse Pointe Park; S. Martin Taylor, Gross Pointe Farms; Katherine E. White, Ann Arbor; Mary Sue Coleman, ex officio 


\title{
The Influence of Public Policy on Health, Wealth and Mortality
}

\begin{abstract}
In this project we extend an augmented lifecycle model, incorporating a Grossman-style model of health capital, to enhance understanding of factors influencing consumption, wealth and health. We develop three primary results when using the model to explore the effects of stylized versions of Medicare and Social Security on wealth and longevity. First, our model calibration implies consumption and health are complements. As health depreciates with age, households will get less utility from consumption than would be in the case of a lifecycle model that does not endogenize health. Second, it appears that forward-looking households, when confronted by a substantially reduced safety net, will respond by reducing consumption and by reducing their health investment and therefore longevity. Third, there is a potentially important difference between short- and long- run responses to policy.
\end{abstract}

Understanding of the process through which life span and quality of life are produced and how this affects the living standards of the elderly is a central challenge of social science research. At one level, the potential mechanisms are clear and can, at the risk of oversimplification, be placed into three categories. First, adverse health shocks may affect the ability to work successfully in the labor market, and hence health affects income. Second, while the link is perhaps less obvious, income may affect health. There are many potential pathways: high income households, for example, may invest more than others in health-producing activities (such as diet or exercise) and may have better access to health care. Third, unobserved factors may contribute to health and income. Patient people (those with low discount rates), for example, may be willing to make long-term investments in health and education. Even if people have identical discount rates, there are undoubtedly idiosyncratic differences across people in their ability to maintain and improve health. 
The varied mechanisms that result in a given individual's health and income (and material well-being) are complex. To better understand the links between health, wealth and aging, we develop a dynamic model of household behavior that blends the model of health capital and production developed by Grossman (1972) and an augmented lifecycle model similar to Scholz, Seshadri, and Khitatrakun (2006). Incorporating health into a lifecycle model of wealth accumulation is useful. Households may respond to adverse income or health shocks or to changes in government policy by adjusting health investment as well as consumption. Changes in health investment can alter individuals' health and have longer-run implications for mortality. To explore these links, however, a behavioral model of household decision-making is needed.

Given exogenous household income, we model the intertemporal consumption/saving decisions and health investments that households make. These adjust to changes in the policy and institutional environment. By modeling health production, we also model longevity. Longevity is an excellent outcome to use when matching model implications with data, since a person's health is difficult to assess with observational data. Indeed, this difficulty underlies many of the most interesting asymmetric information problems in the economics of health and insurance. Death, however, is readily apparent. Many of our policy experiments, therefore, focus on mortality or longevity as a central outcome of interest. It is likely, however, that the effects of policy on health work in similar directions. A policy that enhances longevity is also likely to enhance health.

We examine the effects of Social Security reforms on wealth, health, and longevity in our policy simulations. By explicitly modeling health production, we also provide insights into the determinants of health and factors that affect life-tables (and therefore, Social Security solvency). The model allows us to study the interactions between consumption/saving decisions and the 
production of health capital. The model is well-suited for examining the implications of changes to the health safety net on longevity and hence Social Security financing.

Our model matches quite closely the joint distribution of medical expenditures and wealth over time observed in data. It is perhaps not surprising that we can do that for the average household in the sample, since we calibrate selected underlying behavioral parameters to the behavior of the average (or mean) household in the sample. It is considerably more striking that we match behavior in the tails of the distribution and, more broadly, that we do a reasonable job matching behavior household-by-household after simply calibrating the model to behavior of the average household.

Our economic model of health and wealth is similar to Scholz and Seshadri (2010), though we have made several extensions and improvements. The two most important are: we improve our modeling of health insurance, and we improve the data used in the underlying analysis. In our previously funded work, we did not allow households to have changes in insurance status before and after age 65. For example, if a household had employer-provided insurance during their working life, they retained that status in retirement. This modeling simplification reduced the size of the state space that we needed to solve for our dynamic programming problem, reducing substantially (by a factor of four) the time needed to solve the model. Now, we incorporate insurance status as a state variable, which allows households to transition to our stylized version of the Medicare program when they reach age 65.

In prior work we also made use of a potentially suspect measure of total medical expenses included in one version of the Health and Retirement Study (HRS). While we have reasonable confidence in reported out-of-pocket medical expenses in the HRS, total expenses are considerably more difficult for a household to report accurately in an interview survey. In this 
draft we use moments for total medical expenses by age, cross-classified by insurance status, drawn from the Medical Expenditure Panel Survey (MEPS), to calibrate parameters that map out-of-pocket expenses into total expenses. We also updated and improved all input data for the model, including our empirical models of taxation, transfers, and expectations (about future earnings, health shocks and pensions). We examine a representative sample of households born before 1954. And unlike our prior work, we examine how health and consumption responds to changes in health insurance and Social Security arrangements.

Three primary themes emerge from this project. First, we model health and consumption in a flexible way. As households age, health and consumption could be substitutes. As health diminishes with age, households could consume more to offset their diminished health capital. This might occur, for example, through larger home-health expenditures. Alternatively, health and consumption could be complements. Households in poor health may experience diminished utility from consumption. If health and consumption are complements, forward-looking households will recognize this, shifting consumption to earlier ages where the utility gained from consumption would be higher. Our analysis suggests consumption and health are complements in preferences.

Second, modeling health investment and consumption broadens the scope of potential household responses to policy. Most numerical models of life-cycle consumption do not model health investments. Safety net cuts, therefore, will typically generate a precautionary saving response, where households consume less and save more to self-insure for potential future adverse shocks. Modeling health investment introduces a second margin of adjustment. Rather than sharply dropping consumption, households, when confronted by a substantially reduced safety net, might respond both by reducing consumption and by reducing their health investment. 
Indeed, in some very poor countries, it does not appear that households engage in substantial precautionary saving. Instead, they largely run down their health capital. Our model illustrates these possibilities in a model calibrated to the U.S. economy.

Third, there is a potentially important difference between short- and long-run responses to policy. Because health capital is largely determined by the time an individual reaches retirement, for example, our results imply there would be only negligible effects on mortality rates of eliminating Medicare in the first 10 years following the unanticipated removal of the program. Long-run adjustments to changes in the institutional environment can be substantial, however. In the Medicare application, households will consume less and do more buffer stock saving, selfinsuring after losing Medicare. The self-insurance is not enough to offset the long-run effects of eliminating Medicare. The result is that households will both consume less and die earlier when Medicare is eliminated. The model with endogenous health mitigates the effects of changes in social insurance on consumption relative to standard lifecycle models.

\section{Background}

We, of course, are not the first to examine the links between health, consumption, and wealth. Clear discussions are given in Smith (2005) and Case and Deaton (2005) and by many others. More closely related to our work is an important set of papers, including Palumbo (1999); Kopecky and Koreshkova (2009); and De Nardi, French and Jones (2010) that document the substantial role that late-in-life health shocks, including nursing home expenses and social insurance, play in old age wealth decumulation. While these papers offer valuable insights, they fall short of capturing the varied ways that health and consumption interact in the Grossman framework. In particular, except for the model with exogenous medical expense shocks in Section 9 of De Nardi, French and Jones (2010), the only response that households have to the 
realization of medical expense shocks in these models is to alter consumption. Death occurs through the application of life tables with random longevity draws. ${ }^{1}$

De Nardi, French and Jones (2010) estimate key structural parameters of an intertemporal consumption model with endogenous health investment. They use a sample of single individuals age 70 and over. They find that endogenizing medical expense shocks has little effect on their results. They write, "In sum, the endogenous medical expense model confirms and reinforces our conclusion that medical expenses are a major saving motive and that social insurance affects the saving of the income-rich as well as that of the income-poor. Our main findings appear robust to the way in which we model the medical expense decision." They point out that health capital may be well-formed by prior decisions and expenditures by the time an individual reaches age 70 .

Our work builds on the innovative endogenous medical expense model of De Nardi, French and Jones (2010). We model the process of health production starting at the beginning of working life. We take a more expansive view than prior work of health investments, in that we allow health to be affected by investments of time as well as money. With our model, we study the tradeoff between consumption and health investments on longevity (and health status) and consumption.

\section{HRS Data on Earnings, Wealth, Health and Longevity}

We use data from all waves of the 1992-2008 Health and Retirement Study. The sample includes households from the AHEAD cohort, born before 1924; Children of Depression Age

\footnotetext{
${ }^{1}$ Two related papers model intertemporal consumption decisions and include health in the utility function in a manner similar to our approach. Fonseca, Michaud, Galama, and Kapteyn (2009) write down a model similar to ours and solve the decision problem for 1,500 representative households. Consumption and health are separable in utility in their model and the focus of their work is on explaining the causes behind the increases in health spending and life expectancy between 1965-2005. Yogo (2009) solves a model similar to ours for retired, single women over 65 to examine portfolio choice and annuitization in retirement.
} 
(CODA) cohort, born between 1924 and 1930; the original HRS cohort, born between 1931 and

1941; the War Baby cohort, born between 1942 and 1947; and the Early Baby Boomers, born

between 1948 and 1953. The sample is a representative, randomly stratified sample of U.S.

households born before 1954. The HRS modestly oversamples blacks, Hispanics, and

Floridians.

\section{Self-Reported Health and Exercise Decline with Age}

The descriptive data in the HRS are consistent with the issues raised in the introduction. It is no surprise, of course, that health capital depreciates. Figure 1a shows the evidence from the 2008 wave of the HRS. The data are disaggregated by the five HRS cohorts. Forty-six percent of the youngest group members, the early boomers, are in very good or excellent health. Only 24 percent of the oldest group members, the AHEAD cohort, are in very good or excellent health. Thirty-nine percent are in fair or poor health, while only 25 percent of the early boomers are in fair or poor health. The effects are nearly monotonic with age.

While the direction of causality is not clear, similar patterns hold for exercise (as shown in Figure 1b). Early boomers are more than twice as likely (at 34 percent) than their AHEAD counterparts (16 percent) to engage in moderate exercise every day or vigorous exercise at least once per week. They are three times less likely (at 14 percent) than their AHEAD counterparts (42 percent) to never or rarely exercise. The evidence on exercise, health and age coupled with the well-known fact that it is difficult to observe direct links between medical expenditure and health (the so-called "flat of the curve medicine"), influences the way we model health production. ${ }^{2}$ Factors such as time spent exercising, smoking decisions, and diet appear to play a

\footnotetext{
${ }^{2}$ Card, Dobkin, Maestas (2008), for example, is one of a small number of studies that find expenditures are positively correlated with survival. Their work is based on a very large sample of people admitted to emergency rooms in California: they find the positive effects of spending apply to a small subset of the conditions that lead people to show up in emergency rooms. Doyle (2010) shows that men who have heart attacks when vacationing in
} 
not-insignificant role in determining health status and hence longevity. We take a parsimonious approach to modeling health by monetizing all health-producing activities. For working households, time spent in exercise therefore can be thought of as reducing hours available for income-producing opportunities and therefore reducing consumption possibilities. The Positive Health-Income and Health-Wealth Relationship

Work with the HRS would make little sense if it did not reflect the typical positive relationship between measures of economic affluence - in our case, lifetime income and net worth - and self-reported health status. Figures $2 \mathrm{a}$ and $2 \mathrm{~b}$ show the HRS data are consistent with a strong, positive relationship between lifetime income quintiles and self-reported health (Figure 2a) and net worth quintiles and self-reported health (Figure 2b).

\section{Longevity and Lifetime Income for Men and Women}

There is a strong relationship between lifetime income and survival in the HRS. To show this, we restrict the sample to birth years that, in principle, would allow someone to reach a specific age by the last year of HRS data we have available, 2008. So, for example, when we look at patterns of ten-year survival from age 60 to age 70, we restrict the sample to those born before 1938. To mitigate the problem of survivor bias we also limit the sample to respondents who were first interviewed prior to turning 60 . When we look at survival to age 85 , we condition the sample to those born before 1923 and drop those who were older than 75 in the year they entered the HRS sample. At this stage of our analysis, we also restrict the sample to couples where at least one member allowed researchers to gain access to their Social Security earnings records (under tightly controlled conditions). Our samples for survival to age 70 has 4,707 individuals, our sample for survival to age 85 has 1,865 individuals.

Florida have higher survival probabilities if they end up being served by high- rather than low-expenditure hospitals. Numerous studies, however, suggest significant portions of medical expenditures have little discernible effect on health. 
Figure 3a shows our results on survival probabilities to age 70, tabulated by lifetime income quintile. For men, the survival probabilities increase monotonically with lifetime income, from 74 percent for those in the lowest lifetime income quintile to 89 percent for those in the highest. The survival probabilities for women increase from 79 percent in the lowest lifetime income quintile to 96 percent in the highest.

Figure $3 \mathrm{~b}$ shows similar patterns for mortality to age 85 by lifetime income. ${ }^{3}$ The pattern for males is striking: 62 percent of the men in the highest lifetime income quintile live to 85 (conditional on living to 75 ) while only 42 percent of those in the lowest quintile live to 85 . The gradient exists but is less strong for women.

To summarize, there is a clear relationship between lifetime income and survival. There are many likely explanations for the patterns. We write down and solve a model that captures several of these explanations, though we do not model differences in innate ability to produce health capital. Households in the model have different, exogenous draws on annual earnings, and hence different lifetime incomes. They differ in the timing of exogenous marriage and fertility. Given differences in incomes and demographic characteristics, they will respond to health shocks (which vary by lifetime income), earnings shocks, and government programs in different ways. Moreover, we allow consumption and health to be gross complements or gross substitutes in utility. The work that follows, therefore, illuminates the channels through which health, consumption, and wealth are related.

\footnotetext{
${ }^{3}$ Differential mortality is clearly a concern. Men and women in lower lifetime income quintiles are disproportionately likely to die at an early enough age to never appear in the analysis sample for surviving to age 85 . This leaves the survivors in the low lifetime income quintiles stronger, healthier than the typical household prior to the within-quintile mortality.
} 


\section{Model}

We assume the household maximizes utility by choosing consumption and health investments:

$$
E\left[\sum_{j=S}^{D} \beta^{j-S} n_{j} U\left(c_{j} / n_{j}, l_{j}, h_{j}\right)\right] .
$$

The expectation operator $E$ denotes the expectation over future earnings uncertainty and uncertainty in health expenditures over life span, $\beta$ is the discount rate, $j$ is age, $S$ is the age that a household member entered the labor market, $D$ is the oldest age that people can live to, $c$ is consumption, and $h$ stands for health and $l$ stands for leisure. $n_{j}$ represents the equivalent number of adults in the household and is a function of the number of adults, A, and children, K, in the household $g\left(A_{j}, K_{j}\right)$.

Life span is endogenous in this model, following the work of Grossman (1972). Specifically, we assume that the household possesses a health stock and investments in health can prolong life. The accumulation process of the stock of health is given by

$$
h_{j+1}=i\left(m_{j}, i_{j}\right)+\left(1-\delta_{j}\right) h_{j}+\varepsilon_{j}, j \in\{S, \ldots\}
$$

The above equation shows the evolution of health status across ages. The stock of health in the next age is determined by investments in health, denoted by $i\left(m_{j}, i_{j}\right)$ : investments in health are augmented both by direct medical expenditures and time investments in health capital. Households spend an indivisible amount of time $\omega$ working each period and spend the rest of their time endowment $1-\omega$ on either leisure or on activities that augment health investments. Upon retirement, households split their time endowment of 1 unit between leisure and health investments. Total medical expenditures $m_{j}$ are a function $M(\cdot)$ of out-of-pocket medical 
expenses, $m_{j}^{o o p} . \delta_{j}$ stands for the depreciation rate of health. Introducing age-dependent shocks to health is both realistic and necessary if we are interested in matching biological processes and the data. These age-dependent shocks are denoted by $\varepsilon_{j}$. In typical lifecycle models, medical expenditures have only financial consequences. Here medical expenditures affect health capital which, in turn, affects utility and longevity. The modeling approach mimics the modeling of human capital - additions to human capital can be either consumption or investment as in Becker (1964), Mincer (1974) and the subsequent, vast human capital literature.

We are able to examine the effects of policy on longevity by modeling health. The probability of surviving into the next period is given by the function $\Psi(\mathrm{h})$. This function satisfies two properties. As $h$ goes to $\infty, \Psi(h)$ converges to 1 . Second, $\Psi(h)=0$ for $h \leq 0$. This ensures that as soon as h goes to zero, the household dies. Finally, note that health status affects utility directly.

Consumption and the age of retirement are chosen to maximize expected utility subject to the constraints,

$$
\begin{gathered}
y_{j}=e_{j}+r a_{j}+T\left(e_{j}, a_{j}, j, n_{j}\right), j \in\{S, \ldots, R\}, \\
y_{j}=S S\left(\sum_{j=S}^{R} e_{j}\right)+D B\left(e_{R}\right)+r a_{j}+T_{R}\left(e_{R}, \sum_{j=S}^{R} e_{j}, a_{j}, j, n_{j}\right), j \in\{R+1, \ldots, D\}, \\
C_{j}+a_{j+1}+m_{j}=y_{j}+a_{j}-\tau\left(e_{j}+r a_{j}\right), j \in\{S, \ldots, R\}, \\
C_{j}+a_{j+1}+m_{j}=y_{j}+a_{j}-\tau\left(S S\left(\sum_{j=S}^{R} e_{j}\right)+D B\left(e_{R}\right)+r a_{j}\right), j \in\{R+1, \ldots, D\} .
\end{gathered}
$$


In these expressions $y$ is income, $e$ is earnings, $a$ is assets, $r$ is the interest rate, $T$ is a transfer function, and $R$ is the age of retirement. Social security (SS) is a function of lifetime earnings, defined benefit pensions $(D B)$ are a function of earnings in the last year of life, $\tau$ is a payroll and income tax function, and the transfer function for retirees $\left(T_{R}\right)$ is a function of Social Security, DB pensions, assets, age, and family structure.

\section{$\underline{\text { Retired Household's Dynamic Programming Problem }}$}

A retired household after age $R$ obtains income from Social Security, defined benefit pensions, and preretirement assets. The dynamic programming problem at age $j$ for a retired household is given by

$$
V\left(e_{R}, E_{R}, a, j, h\right)=\max \left\{n U(c / n, 1-i, h)+\beta \Psi(h) \int V\left(e_{R}, E_{R}, a, j+1, h^{\prime}\right) d \Xi(\varepsilon)\right\}
$$

subject to

$$
\begin{gathered}
\mathrm{y}=\mathrm{SS}\left(\mathrm{E}_{\mathrm{R}}\right)+\mathrm{DB}\left(\mathrm{e}_{\mathrm{R}}\right)+\mathrm{ra}_{\mathrm{j}}+\mathrm{T}_{\mathrm{R}}\left(\mathrm{e}_{\mathrm{R}}, \mathrm{E}_{\mathrm{R}}, \mathrm{a}, \mathrm{j}, \mathrm{n}\right) \\
\mathrm{c}+\mathrm{a}^{\prime}+\mathrm{m}^{\text {oop }}=\mathrm{y}+\mathrm{a}-\tau\left(\mathrm{SS}\left(\mathrm{E}_{\mathrm{R}}\right), \mathrm{DB}\left(\mathrm{e}_{\mathrm{R}}\right)+\mathrm{ra}\right) \\
h^{\prime}=F\left(M\left(m^{o o p}\right), i\right)+\left(1-\delta_{h}\right) h+\varepsilon
\end{gathered}
$$

In the above equation the value function, $V\left(e_{R}, E_{R}, a, j, h\right)$, denotes the present discounted value of maximized utility from age $j$ until the date of death, the ' superscript denotes the corresponding value in the following year; and, as noted before, $\Psi(h)$ denotes the probability of survival between ages $j$ and $j+1$ for the husband and the wife respectively. $m^{o o p}$ are out-of-pocket medical expenses. Total earnings up to the current period are denoted by $E_{R}$ while the last earnings draw at the age of retirement is $e_{R}$. Note that these values do not change once the household is retired. 


\section{Working Household's Dynamic Programming Problem}

A working household between the ages $S$ and $R$ obtains income from labor earnings and preretirement assets. The dynamic programming problem at age $j$ for a working household is given by

$$
V\left(e, E_{-1}, a, j, h\right)=\max \left\{n U(c / n, 1-\omega-i, h)+\beta \Psi(h) \int V\left(e^{\prime}, E, a^{\prime}, j+1, h^{\prime}\right) d \Xi(\varepsilon)\right\}
$$

subject to

$$
\begin{gathered}
\mathrm{y}=\mathrm{e}+\mathrm{ra}+\mathrm{T}(\mathrm{e}, \mathrm{a}, \mathrm{j}, \mathrm{n}) \\
\mathrm{c}+\mathrm{a}^{\prime}+\mathrm{m}^{\mathrm{oop}}=\mathrm{y}+\mathrm{a}-\tau(\mathrm{e}+\mathrm{ra}) \\
h^{\prime}=F\left(M\left(m^{o o p}\right), i\right)+\left(1-\delta_{h}\right) h+\varepsilon
\end{gathered}
$$

$V\left(e, E_{-1}, a, j, h\right)$ denotes the present discounted value of maximized utility from age $j$.

$E_{-1}$ are cumulative earnings up to the current period. The other variables are defined above.

\section{Data}

A critical input to our calculations is household earnings. We start with individual earnings, which, after adjusting missing and top-coded observations, we aggregate for households. Earnings data come from three sources: Social Security Administration Summary Earnings files, SSA earnings detail files (W-2 information), and HRS self-reports. We added new earnings data through 2007 using the 2009 SSA Summary Earnings file.

Earnings in the Summary Earnings files are top-coded. To "undo" top-coding, we first check to see if W-2 earnings records exist; these data are available for most respondents starting in 1978. If W-2 data are not available, HRS self-reports of earnings are used (if available).

The remaining top-coded earnings observations are split into two windows, 1951-1977 and 1978-2007. In the first period no top-coded earnings are recovered from W-2 or HRS data. We 
then estimate a censored regression model to predict the top-coded earnings in each year using the following covariates: gender, education, birth year, race, Census region, marital status, average percentile in the earnings distribution over the past 5 years (if available), average percentile in the earnings distribution over the next 5 years (if available), number of children in the household, total years reported working, and average real household wealth over the HRS study years (1992, 1994, ...2008). The covariates are drawn from the first wave the respondent appears in the HRS.

In the second window, 1978 - 2007, we recover many top-coded earnings observations from W-2 data. We then estimate an earnings model with the same covariates mentioned previously, using the high-income observations that were recovered from the W-2 and HRS data. We use these estimates to predict earnings for the high-income observations that remain top-coded. We add a new covariate in 1992, labor force status, and the covariates used for prediction are taken from the nearest HRS interview.

Missing earnings are filled in when possible using HRS responses. Missing earnings in years following the respondent's last year of work or retirement year are set to zero. Missing earnings are set to zero for respondents who report never having worked. Missing earnings for respondents younger than age 17 are also set to zero. The remaining missing earnings are imputed via an earnings model using most of the variables listed above. The difference is that instead of using their point in the earnings distribution, the respondent's average real earnings in the past/next five years was used when available.

After aggregating individual earnings to the household level, we combine earnings with data on household demographics, work history and pension status. 
For analytic tractability we assume earnings are exogenous and therefore unaffected by changes in policy. While this assumption is strong, decision rules in the model and underlying data are household-specific. In particular, income in the model is a precise measure of annual household income drawn from Social Security earnings records. These income observations reflect all shocks the household received (including health and marital shocks) that affect income. Hence, the income data we use reflects the full array of health shocks households receive over their lifetime, their investments in health-related activities, and all other factors affecting income draws. What we do not accommodate at this point in our research program is for counterfactual policy changes to affect the incomes households receive. Social Security

We estimate the household's expected Social Security benefit using the earnings history for each household member. We take into account changes over time in the Social Security rules (e.g., full retirement age, penalty for early claiming, credit for late claiming, and breakpoints used in the determination of primary insurance amount) so that each household forms expectations about Social Security benefits that reflect the rules in place at the time the household head reaches their retirement age.

\section{Model Parameterization and Calibration}

In this section, we specify functional forms and parameter values that we use to solve the model. We start by specifying functional forms for utility and health production. We then set some parameter values based on information from the literature or from reduced form estimates from the HRS. We identify the other model parameters by fitting the predictions of the model for the average household to data on wealth accumulation, medical expenses and survival 
probabilities. Once we have these parameter values, we then solve the model household-byhousehold to examine predictions for every household in our sample.

\section{Preferences}

We assume that a household's utility function takes the form

$u(c, h)=\frac{\left[\lambda\left(c^{\eta} l^{1-\eta}\right)^{\rho}+(1-\lambda) h^{\rho}\right]^{\frac{1-\gamma}{\rho}}}{1-\gamma}$. The elasticity of substitution between the consumptionleisure composite and health is $\frac{1}{(1-\rho)}$. The parameter $\gamma$ is the coefficient of relative risk aversion. Given that the choice of whether to invest in health and hence prolong life is endogenous, the coefficient of relative risk aversion $\gamma$ needs to be less than 1 . This guarantees that utility is a positive number. Similar assumptions are made in the endogenous fertility literature. The discount factor $(\beta)$ is set at 0.96 , a value similar to the 0.97 value used in Hubbard, Skinner, and Zeldes (1995); and Engen, Gale, and Uccello (1999). We also set $\eta$ $=0.36$ from Cooley and Prescott (1995).

\section{Equivalence Scale}

Like Scholz, Seshadri and Khitatrakun (2006) and Scholz and Seshadri (2010) we use an equivalence scale drawn from Citro and Michael (1995):

$$
g(A, K)=(A+0.7 K)^{0.7}
$$

where again, $A$ indicates the number of adults and $K$ indicates the number of children in the household.

\section{Rate of Return}

We assume an annualized real rate of return ( $r$ ) of 4 percent. This assumption is consistent with McGrattan and Prescott (2003), who find that the real rate of return for both equity and debt 
in the United States over the last 100 years, after accounting for taxes on dividends and diversification costs, is about 4 percent.

Taxes

We model an exogenous, time-varying, progressive income tax that takes the form

$$
\tau(y)=a\left(y-\left(y^{-a_{1}}+a_{2}\right)^{\frac{-1}{a_{1}}}\right)
$$

where $y$ is in thousands of dollars. Gouveia and Strauss $(1994,2000)$ estimate the parameters ( $a, a_{1}$, and $a_{2}$ ) of the tax function using micro (or individual tax return data). Their estimates characterize U.S. effective, average household income taxes between 1966 and 1989 . We need parameters for a longer period. So we assembled data by aggregated income classes from 1950 to 2008 using IRS data from the Statistics of Income Division of the Internal Revenue Service, available electronically through the Boston Public Library. We used these data to estimate the parameters of the tax function in each year: 1950 to 2008.

\section{Earnings Process}

Earnings expectations are a central influence on life-cycle consumption and health accumulation decisions, both directly and through their effects on expected pension and Social Security benefits. We aggregate individual earnings histories into household earnings histories. The household model of log earnings (and earnings expectations) is

$$
\begin{gathered}
\log \left(e_{j}\right)=\alpha^{i}+\beta_{1} A G E_{j}+\beta_{2} A G E_{j}^{2}+u_{j} \\
u_{j}=\rho u_{j-1}+\varepsilon_{j}
\end{gathered}
$$

where, as mentioned above, $\varepsilon_{j}$ is the observed earnings of the household $i$ at age $j$ in 2004 dollars, $\alpha^{i}$ is a household specific constant, $A G E_{j}$ is age of the head of the household, $u_{j}$ is an 
$\mathrm{AR}(1)$ error term of the earnings equation, and $\varepsilon_{j}$ is a zero-mean i.i.d., normally distributed error term. The estimated parameters are $\alpha^{i}, \beta_{1}, \beta_{2}, \rho$ and $\sigma_{\varepsilon}$.

We divide households into six groups according to marital status, education and the number of earners in the household, resulting in six sets of household-group-specific parameters. ${ }^{4}$ The parameters for each of these six groups are estimated separately for the five HRS cohorts.

We estimate a similar medical expense expectation function using parameters of an out-ofpocket medical expense function for each of four different household types (single vs. married, college vs. no college).

For households receiving a defined benefit pension we estimate a DB pension expectation function based on parameters of a function giving the annual value of pension benefits.

\section{Transfer Programs}

One purpose of this paper is to assess the importance of factors affecting health and household wealth, including the safety net. We model public income transfer programs using the specification in Hubbard, Skinner and Zeldes (1995). Specifically, the transfer that a household receives while working is given by

$$
T=\max \{0, \underline{c}-[e+(1+r) a]\}
$$

whereas the transfer that the household receives upon retiring is

$$
T=\max \left\{0, \underline{c}-\left[S S\left(E_{R}\right)+D B\left(e_{R}\right)+(1+r) a\right]\right\}
$$

This transfer function guarantees a pre-tax income of $\underline{c}$, which captures the value of AFDC/TANF, food stamps and Medicaid received by a family with no income. Moffitt (2002)

\footnotetext{
${ }^{4}$ The groups are (1) married, head without a college degree, one earner; (2) married, head without a college degree, two earners; (3) married, head with a college degree, one earner; (4) married, head with a college degree, two earners; (5) single with college degree; and (6) single without a college degree. A respondent is an earner if his or her lifetime earnings are positive and contribute at least 20 percent of the lifetime earnings of the household.
} 
provides estimates for the years 1960, 1964, 1968 to 1998 . We extended this series through 2008 by gathering data on government aid programs through 2008 from a variety of sources (Urban Institute, Mathematica Policy Research Inc., Center for Medicare and Medicaid Services, a database compiled by James Ziliak at the University of Kentucky). These data are at the state level so we take a weighted average based on state population in each year.

Subsistence benefits for a one-parent family with two children increased sharply, from \$5,992 in 1968 to $\$ 9,887$ in 1974 (all in 1992 dollars). Benefits have trended down from their 1974 peak - in 1992 the consumption floor was $\$ 8,159$ for a one-parent, two-child family. Following Hubbard, Skinner, and Zeldes, this formulation implies that earnings, retirement income, and assets reduce public benefits dollar for dollar.

Health production

We assume that the production of health is given by the iso-elastic form $F\left(M\left(m^{o o p}\right), i\right)=\left(m^{\chi} i^{1-\chi}\right)^{\xi}$, where $m=M\left(m^{o o p}\right)$. Recall that $i$ denotes time allocated to the production of health capital. Total medical expenditures are related to out-of-pocket medical expenditures by a linear function that varies by insurance status. Specifically, we calibrate the $m=\varsigma\left(m^{\text {oop }}\right)$ function for those under and over 65 . The categories include any private under 65 , public only under 65, and uninsured under 65; and for those over 65, Medicare only, Medicare plus private insurance; and Medicare plus other public insurance.

Survival Probability

The probability of surviving into the next period is given by the function $\Phi(h)$. We assume this function satisfies two properties. As h goes to $\infty, \Phi(h)$ converges to 1 . Second, $\Phi(h)=0, h \leq 0$, which ensures that as soon as $h$ goes to zero, the household dies. Finally, note that health status also affects utility directly. 


\section{Health Shocks}

At each age, we assume that there are two possible values for the health shocks: $\varepsilon_{h}$ and $\varepsilon_{l}$. The first shock $\varepsilon_{h}$ corresponds to being healthy and is set to zero. The magnitude of the health shock $\varepsilon_{l}$ is determined by the calibration procedure. The probability of the second shock is assumed to vary by age: $p_{55}, p_{65}, p_{75}, p_{85}$, and $p_{100}$ refer to probabilities of 'bad' health shocks between the ages of 0-55, 55-65, 65-75, 75-85 and over 85 respectively.

\section{Calibration}

While many parameters are set based on estimates from the literature or by estimating reduced form empirical models from the HRS, additional critical parameters still need to be specified. We use information on asset holdings, life tables and average medical expenses for the average household in the HRS to pin down these parameters. The parameters we calibrate are $\lambda, \rho, \gamma, \psi, \theta, \xi, \varepsilon_{1}, \chi, \delta_{h} p_{55}, p_{65}, p_{75}, p_{85}$, and $p_{100} \cdot{ }^{5}$ To calculate these remaining parameters, we solve the dynamic programming problem for the average household - the household with average earnings over their lifetime. We then use the decision rules in conjunction with observed histories of earnings to obtain model predictions. To match moments on total medical expenses, we integrate out the lifetime sequence of health shocks before arriving at the model predictions for a given age. We then seek to obtain the best fit between model and

\footnotetext{
${ }^{5}$ To remind readers, these are $\lambda$ (the utility weight on consumption relative to health), $\rho$ (determines the elasticity of substitution between consumption and health), $\gamma$ (the coefficient of relative risk aversion), $\psi$ (the coefficient on health in the survival function), $\theta$ (the curvature of the survival function with respect to health), $\xi$ (the curvature of the health production function), $\varepsilon_{l}$ (the magnitude of the "bad" health shock), $\chi$ (the share parameter in health production between monetary and time inputs), $\delta_{h}$ (the annual depreciation rate of health), and $p_{55}, p_{65}, p_{75}, p_{85}$, and $p_{100}$ (the probabilities of bad health shocks occurring at different age intervals).
} 
data relative to the moments we seek to match. The moments we use to identify and pin down the parameters are:

1. $\quad$ Mean net worth in 1998 (age 65.3):

$\$ 346,221$

2. Probability of dying age 54 and under:

$0.62 \%$

3. Probability of dying 60-64:

$4.34 \%$

4. Probability of dying 70-74:

$9.84 \%$

5. $\quad$ Probability of dying 75-79:

$11.84 \%$

6. $\quad$ Probability of dying $80-84$ :

$19.35 \%$

7. Probability of dying 90-94:

$41.73 \%$

8. Probability of dying in the next 5 years for those 95 and older:

$72.73 \%$

9. Average total medical expenses under age 18-44:

$\$ 2,974$

10. Average total medical expenses for ages50-54 :

11. Average total medical expenses for ages 60-64:

$\$ 4,974$

12. Average total medical expenses for ages 70-74:

$\$ 8,472$

13. Average total medical expenses for ages75-79:

$\$ 9,083$

14. Average total medical expenses for ages 80 and older:

$\$ 10,006$

$\$ 10,511$

Essentially, this represents 14 non-linear equations in 14 unknowns. We obtained an exact match between the model predictions and the moments above and the resulting parameter values are given in the Table below.

\begin{tabular}{|c|c|}
\hline Parameter & Value \\
\hline$\lambda$ & 0.81 \\
\hline$\rho$ & -6.8 \\
\hline$\gamma$ & 0.83 \\
\hline$\psi$ & 0.0013 \\
\hline$\xi$ & 1.68 \\
\hline$\varepsilon_{1}$ & 0.75 \\
\hline$\chi$ & -15.3 \\
\hline$\delta_{h}$ & 0.51 \\
\hline$p_{55}$ & 0.049 \\
\hline$p_{65}$ & 0.05 \\
\hline$p_{75}$ & 0.10 \\
\hline$p_{85}$ & 0.135 \\
\hline$p_{100}$ & 0.186 \\
\hline
\end{tabular}

Notice that $\lambda$ is less than 1 and the resulting preferences are close to logarithmic. Recall that this parameter needs to be less than unity to guarantee that utility is a strictly positive 
number. Next, the elasticity of substitution between consumption (more precisely, the composite

of consumption and leisure) and health is $\frac{1}{1-\rho}=0.13$. Consumption and health are

complements, as found by Murphy and Topel (2006) and Finkelstein, Luttmer, and Notowidigdo (2009). The rate of depreciation of health is around 5.6 percent. The share of goods in the production of health $\chi$ is 0.51 , suggesting that time and goods are both important in the production of health. A bad health shock, $\varepsilon_{l}$, takes on the value -15.3: recall that a good health shock, $\varepsilon_{h}$, is set to 0 . Finally, note that the probability of a bad health shock increases from around 5 percent for households below 55 years of age to 10 percent for households between 55 and 65, to 13.5 percent for households between 65 and 75, to 18.6 percent for households between 75 and 86 and to 23.9 percent for households above the age of 85 .

\section{Model Solution}

Once we have the calibrated parameters, we solve the dynamic programming problem by linear interpolation on the value function. For each household in our sample, we compute optimal decision rules for consumption (and hence asset accumulation) and health investments from the oldest possible age (this is endogenous) to the beginning of working life (S) for any feasible realizations of the random variables: earnings and health shocks. These decision rules differ for each household, since each faces stochastic draws from different earnings distributions (recall that this is household specific). Household-specific earnings expectations also directly influence expectations about Social Security and pension benefits. Other characteristics also differ across households. Consequently, it is not sufficient to solve the life-cycle problem for just a few household types. 


\section{Results}

As described above, we calibrate key model parameters to the average household in the data. A first check of the usefulness of the model we develop is to examine its ability to match the distribution of outcomes observed in the data. We focus on the ability of the model to match the data on asset accumulation and medical expenditures, examining median values by lifetime income. Lifetime income is defined within four roughly equal-sized age groups: under 60, 60 to 65, 66 to 75, and over 75. This relationship is given in the table below.

\begin{tabular}{l} 
Table 1: Model Predictions and Data on Net Worth and Total Medical Expenditures, \\
2008 dollars \\
\hline
\end{tabular}

The model does a credible job matching the wide variation in wealth. Like Scholz, Seshadri, and Khitatrakun (2006), households on average appear to accumulate more wealth than the model suggests is optimal. Simultaneously, the model is able to match to account for the rather large disparities in medical spending across lifetime income quintiles, from close to $\$ 6,000$ for the lowest quintiles to a little more than $\$ 12,000$ for the top quintile annually. The upshot is that the model is capable of explaining a great deal of the dispersion in health investments and wealth that we observe. 


\section{Mortality}

A novel feature of our economic model is that it allows us to examine the effects of policy changes on mortality. But the confidence readers have with our mortality results will depend, in part, on the ability of the model to reproduce mortality patterns in the HRS. To examine mortality, we take 10-year mortality probabilities in the HRS for two groups - those who are 60 years old and those who are 75 years old. To implement this in the HRS (for the case of 60 year olds), we took everyone who entered the HRS in 1992, 1994 or 1996 who were in the age range 58 to 62 . We then examine their mortality over the subsequent 10 years. We then make similar calculations for the age 75 sample. The entries in the table below under "Data" give the survival probabilities by lifetime income quintile. ${ }^{6}$

\begin{tabular}{|l|c|c|c|c|}
\hline Table 2: Ten-year Survival Probabilities, HRS Data and Model \\
\hline & \multicolumn{2}{|c|}{ Age 60 } & \multicolumn{2}{c|}{ Age 75 } \\
\hline & Data & Model & Data & Model \\
\hline Bottom Lifetime Quintile & 0.77 & 0.74 & 0.5 & 0.5 \\
\hline Second Quintile & 0.82 & 0.79 & 0.52 & 0.51 \\
\hline Third Quintile & 0.86 & 0.83 & 0.52 & 0.55 \\
\hline Fourth & 0.90 & 0.85 & 0.63 & 0.57 \\
\hline Highest & 0.93 & 0.87 & 0.65 & 0.60 \\
\hline
\end{tabular}

The mortality calculations implied by the model require considerable calculation. We take all 60 year olds. These households face many different patterns of potential health shocks. We integrate out over all potential sequences between the ages 60 and 70 and calculate the mass of survivors. These calculations require, of course, the optimal decision rules over the lifetime of households. We make similar calculations for households age 75 . The mortality rates implied by the model are given in Table 2 under the column "Model."

\footnotetext{
${ }^{6}$ These numbers from the HRS data are simply the population averages of the gender-specific survival probabilities plotted in Figures 3a and 3b.
} 
The model does a good job matching mortality patterns in the underlying data, though seven of the 14 moments that we calibrate the model to tie down mortality probabilities by age for households with average lifetime incomes. This does not, however, imply that we would expect the model to reproduce mortality patterns for high- or low-lifetime income quintile households. The most important deviations between mortality data and predictions occur for households in the highest lifetime income quintiles. These are likely to be the households that are most efficient in producing health capital. What is the effect of Medicare on longevity?

We now use the model to examine the effects of removing our stylized version of Medicare, ${ }^{7}$ the universal social insurance program that was established in 1965 to provide health insurance to the elderly. There are several reasons why we focus on this policy. First, Medicare is a large social insurance program costing $\$ 486$ billion in fiscal year 2007. Second, end-of-life health shocks have been shown by several authors to have significant effects on asset accumulation. Third, Finkelstein and McKnight (2008) show, for example, that in the first 10 years following the establishment of Medicare, there was no discernible effect on mortality. The effects of policy changes on mortality and asset accumulation in the short- and long-run are issues the model is nicely designed to address.

The policy experiment that we model is extreme, in the sense that Medicare taxes are still collected but benefits are eliminated. This scenario is nevertheless useful as it illustrates the point that health capital takes time to build up - the short-run responses to policy can differ substantially from long-run policies. ${ }^{8}$ Suppose that Medicare were instantly eliminated (but taxes are not changed and there are no general equilibrium effects from changes in the

\footnotetext{
${ }^{7}$ Specifically, the age-dependent health shocks in the model do not reduce directly the resources available for consumption and health investments for those covered by Medicare (those over 65 in the model in 2008).

${ }^{8}$ As our work develops, we will develop more refined versions of the policy experiments.
} 
government’s fiscal position). Moreover, we assume the change was not anticipated, so the assets and health capital that households have accumulated were acquired under the assumption that Medicare would exist. After eliminating Medicare, we can re-compute the model and examine the effects on 10-year survival probabilities.

\begin{tabular}{|l|c|c|c|c|}
\hline $\begin{array}{l}\text { Table 3: Immediate Ten-Year Survival Probabilities After Eliminating Our Stylized } \\
\text { Version of Medicare Benefits }\end{array}$ \\
\hline & \multicolumn{2}{|c|}{ Age 60 } & \multicolumn{2}{c|}{ Age 75 } \\
\hline & Baseline & No Medicare & Baseline & No Medicare \\
\hline Bottom Lifetime Quintile & 0.74 & 0.73 & 0.50 & 0.49 \\
\hline Second Quintile & 0.79 & 0.77 & 0.51 & 0.50 \\
\hline Third Quintile & 0.83 & 0.82 & 0.55 & 0.54 \\
\hline Fourth & 0.85 & 0.85 & 0.57 & 0.57 \\
\hline Highest & 0.87 & 0.86 & 0.60 & 0.59 \\
\hline
\end{tabular}

As can be seen from Table 3, the short-run effects on mortality of eliminating the stylized Medicare are trivially small, despite the extreme nature of the policy. This suggests the possibility that much of the influence that Medicare has on health outcomes occurs through decisions households make about their health capital well before they reach age 60. Indeed, since most accumulation of health capital and wealth occurs well before retirement, health status is largely fixed by age 60-65. Medicare in the model, therefore, has little effect on health in the years immediately following its repeal. While Medicare provides insurance against adverse health shocks in old age so its elimination is costly to household consumption, our mortality results are consistent with the empirical findings of Finkelstein and McKnight: eliminating Medicare has a small effect on 10-year survival probabilities immediately following repeal in our model.

The long-run effect of Medicare repeal

We now look at the long-run effect of repealing Medicare, comparing model predictions for assets and survival in worlds with and without Medicare. In the context of our model, this means 
we compute lifetime decisions of households where they correctly understand that there is no Medicare. The lifetime budget constraints of households in the previous and current simulations are the same - households in the model have the same exogenous earnings. In the short-run simulation, they reach retirement only to learn that the program does not exist (contrary to expectations). In this simulation they understand from the beginning of their working life that there is no social insurance program that covers health shocks in old age.

We first look at long-run mortality patterns. Medicare repeal now has a large effect on survival probabilities, particularly in the lowest lifetime income quintile. In the long-run, a forward-looking household with low lifetime income recognizes they have no health insurance program in retirement. They also correctly anticipate the lifecycle pattern of health shocks and the cumulative effects of health depreciation, so old-age health status will be worse than health status at younger ages. Because health and consumption are complements, the life-cycle pattern of consumption mirrors the lifecycle pattern of health. Low lifetime income households will therefore invest less in health, trading off a shorter expected lifespan for greater consumption in younger ages when the marginal utility of consumption is high relative to later in life. High lifetime income households mitigate these effects by self-insuring: they engage in buffer stock saving and invest in health capital. 


\begin{tabular}{|l|c|c|c|c|}
\hline $\begin{array}{l}\text { Table 4a: Long-Run Ten-Year Survival Probabilities After Eliminating Our Stylized } \\
\text { Version of Medicare Benefits }\end{array}$ \\
\hline & \multicolumn{2}{|c|}{ Age 60 } & \multicolumn{2}{c|}{ Age 75} \\
\hline & Baseline & No Medicare & Baseline & No Medicare \\
\hline Bottom Lifetime Quintile & 0.74 & 0.66 & 0.50 & 0.43 \\
\hline Second Quintile & 0.79 & 0.72 & 0.51 & 0.47 \\
\hline Third Quintile & 0.83 & 0.79 & 0.55 & 0.50 \\
\hline Fourth & 0.85 & 0.83 & 0.57 & 0.56 \\
\hline Highest & 0.87 & 0.86 & 0.60 & 0.59 \\
\hline
\end{tabular}

The effects of this experiment on wealth are somewhat surprising to us, and perhaps influenced substantially by our modeling of insurance transitions. This reflects the preliminary nature of the work. In the long-run simulations, we anticipated that some households would engage in aggressive buffer stock saving, since they would need to self-insure given there is no social insurance program that would provide health insurance in old age. While in Table 4b below we see greater wealth accumulation, particularly in the lowest lifetime income quintiles, the magnitude of the effects is considerably smaller than we anticipated. Similarly, we do not see large effects on optimal medical expenditures across lifetime income quintiles. We think a computational simplification we have made has a potentially large effect on the long-run results shown in Tables 4a and 4b. Many households in the model are under 65 (roughly half the sample is under 65). Most of these households have employer-provided insurance. As we have modeled the problem, they retain their insurance status for their entire lives, thus avoiding the need to add another state variable to the model (insurance status). Adding state variables is computationally demanding. Hence, fewer households are modeled as being affected by eliminating Medicare than ideally should be, particularly in the upper lifetime income quintiles. As our research develops further, we will address this model limitation. Even with this specification, however, two points are clear - health capital is built over time. Much of one's 
health at older ages reflects investments and decisions made at earlier ages. Second, policy changes may have substantially different effects in the short and long run. In particular, adaptations in the long run can affect consumption and health investment, which in turn may affect longevity.

\section{Table 4b: Long-Run Model Predictions and Data on Net Worth and Total Medical Expenditures, 2008 dollars, After Eliminating Medicare}

\begin{tabular}{|l|c|c|c|c|}
\hline & \multicolumn{2}{|c|}{ Median Net Worth } & \multicolumn{2}{c|}{ Median Medical Expenses } \\
\hline & Baseline & No Medicare & Baseline & No Medicare \\
\hline Bottom Lifetime Quintile & $\$ 24,357$ & $\$ 56,472$ & $\$ 5,963$ & $\$ 2,332$ \\
\hline Second Quintile & 49,583 & 75,786 & 6,647 & 4,147 \\
\hline Third Quintile & 91,980 & 121,213 & 7,512 & 6,231 \\
\hline Fourth & 143,261 & 182,093 & 9,452 & 8,139 \\
\hline Highest & 315,983 & 342,104 & 12,034 & 11,234 \\
\hline
\end{tabular}

The Long-run Effects of Social Security

The final thought experiment is designed to further our understanding of the effect of Social Security on mortality and asset accumulation. In our model, Social Security has two distinctive features relative to Medicare. First, it is not a tied transfer - Social Security benefits are not targeted at medical expenses and may be used by the household to enhance consumption or longevity. Second, the benefit structure of Social Security ensures it has a larger redistributive component than Medicare. In the tables below, we present the effect of eliminating the Social Security system on longevity and on net worth and medical expenses.

Like the Medicare simulations, the Social Security experiments are extreme versions of policy. Namely, earnings do not adjust, so, in a modeling sense, households continue to pay Social Security taxes but simply do not receive any benefits. The lifetime resources shock to low lifetime income households is larger (in a relative sense) than it is to high lifetime income households as a consequence of Social Security's redistributive component. In subsequent 
simulations, we will model the effects of Social Security on wealth and longevity assuming the incidence of Social Security taxes is borne fully by workers. Then earnings over the working life will be higher by the amount of Social Security taxes people pay. Social Security will still have subtle behavioral effects in this reformulated simulation, since the market failures we model the absence of complete insurance markets and borrowing constraints - will affect households' responses to eliminating Social Security in a balanced-budget sense. But the more extreme policy simulation we model here helps clarify channels at work in our behavioral model.

\begin{tabular}{|c|c|c|c|c|}
\hline & \multicolumn{2}{|c|}{ Age 60} & \multicolumn{2}{|c|}{ Age 75} \\
\hline & Baseline & No SS & Baseline & No SS \\
\hline Bottom Lifetime Quintile & 0.74 & 0.70 & 0.50 & 0.46 \\
\hline Second Quintile & 0.79 & 0.75 & 0.51 & 0.48 \\
\hline Third Quintile & 0.83 & 0.79 & 0.55 & 0.52 \\
\hline Fourth & 0.85 & 0.84 & 0.57 & 0.56 \\
\hline Highest & 0.87 & 0.87 & 0.60 & 0.60 \\
\hline
\end{tabular}

\begin{tabular}{|l|l|c|c|c|}
\hline \multicolumn{5}{|l|}{$\begin{array}{l}\text { Table 5b: Long-Run Model Predictions and Data on Net Worth and Total Medical } \\
\text { Expenditures, 2008 dollars, After Eliminating Social Security }\end{array}$} \\
\hline & \multicolumn{2}{|c|}{ Median Net Worth } & \multicolumn{2}{|c|}{ Median Medical Expenses } \\
\hline & Baseline & No SS & Baseline & No SS \\
\hline Bottom Lifetime Quintile & 24,357 & 41,103 & 5,963 & 4,495 \\
\hline Second Quintile & 49,583 & 64,039 & 6,647 & 5,156 \\
\hline Third Quintile & 91,980 & 106,423 & 7,512 & 6,920 \\
\hline Fourth & 143,261 & 156,938 & 9,452 & 8,825 \\
\hline Highest & 315,983 & 327,351 & 12,034 & 11,663 \\
\hline
\end{tabular}

When Social Security is eliminated, households increase their private savings to smooth consumption across time. At the same time, poor households experience a drop in income by more than their richer counterparts. Hence, the negative income effect leads to a cutback in medical spending. This leads to higher mortality at both age 60 and at age 75 . We are anxious to explore the degree to which changes in health investments mitigate the consumption responses 
to transfer policy changes. Lifecycle models in the literature do not endogenize health investment, so all household responses to policy occur through changes in precautionary saving. These responses are overstated when households can adjust by altering their health investments or labor supply (including retirement dates). In subsequent work, we will further expand our model to account for these responses.

\section{Conclusions}

Our research program is still a work in progress, so we want to be careful to not over-reach in drawing conclusions from our work to date. We nevertheless think our modeling suggests four things. First, it is computationally feasible to embed a Grossman-style model of health capital into an augmented lifecycle model of consumption. Doing so allows us to study two behavioral responses that to date have not been explored: the tradeoff between consumption and health investments and the effects of policy on longevity. Existing models will overstate the effects of policy on consumption/saving/wealth by ignoring the likelihood that people may respond to adverse shocks by altering health investments (whether through direct expenditures or through their health-promoting investments of time).

Second, our model calibration implies consumption and health are complements. This implies that as health depreciates with age, households will get less utility from consumption than would be in the case of a lifecycle model that does not endogenize health. This result has implications for the timing of consumption over the lifecycle, and practical implications for the amount of wealth households will want to accumulate to maintain living standards in retirement. Indeed, these wealth targets will be lower than would occur in models without healthconsumption interactions. 
Third, while we need to be very cautious about the channel, due to the extreme nature of our policy experiments to date, it appears that forward-looking households, when confronted by a substantially reduced safety net, might respond both by reducing consumption and by reducing their health investment. Indeed, in some very poor countries, it does not appear that households engage in substantial precautionary saving. Instead, they largely run down their health capital. Large policy changes can affect survival probabilities of low lifetime income households.

Fourth, there is a potentially important difference between short- and long-run responses to policy. Short-run changes in survival probabilities, even to very large policies affecting the elderly, appear to be small because health capital is largely determined by the time an individual reaches retirement. Long-run changes can be substantial, however. With fewer lifetime resources, households will both consume less and die earlier. The consumption/saving responses in a model with endogenous health will be smaller than those in a model that ignores these channels. But it provides a more complete understanding of policy by capturing effects on health and longevity as well as consumption.

\section{$\underline{\text { References }}$}

Becker, G. S., 1964, Human Capital: A Theoretical and Empirical Analysis, with Special Reference to Education. New York: National Bureau of Economic Research.

Card, David, Carlos Dobkin, Nicole Maestas, "Does Medicare Save Lives?" Quarterly Journal of Economics, May 2009, Vol. 124, No. 2: 597--636.

Case, Ann and Angus Deaton, "Broken Down by Work and Sex: How Our Health Declines," in D. Wise (ed.) Advances in the Economics of Aging. University of Chicago Press, 2005.

Citro, Constance F. and Robert T. Michael. 1995. Measuring Poverty: A New Approach. Washington, D.C.: National Academy Press.

Cooley, Thomas F. and Ed Prescott, 1995, "Economic Growth and Business Cycles," Chapter 1 in T. F. Cooley, ed., Frontiers of Business Cycle Research, (Princeton University Press), 1-38. 
De Nardi, Mariacristina, Eric French, and John Bailey Jones, 2010, "Why Do the Elderly Save? The Role of Medical Expenses," Journal of Political Economy

Doyle, Joseph J, Jr, "Returns to Local-Area Health Care Spending: Using Health Shocks to Patients Far from Home," May 2009.

http://www.mit.edu/ jjdoyle/doyle_vacation_aer_may2009.pdf

Engen, Eric M., William G. Gale and Cori R. Uccello. 1999. "The Adequacy of Retirement Saving." Brookings Papers on Economic Activity 2: 65--165.

Finkelstein, Amy, Erzo Luttmer, and Matthew Notowidigdo, 2009, "What Good is Wealth without Health? The Effect of Health on the Marginal Utility of Consumption," NBER Working Paper No. 14089, (revised).

Finkelstein, Amy and Robin McKnight, 2008, "What Did Medicare Do? The Initial Impact of Medicare on Mortality and Out of Pocket Medical Spending," Journal of Public Economics, 92, 1644-1669.

Fonseca, Raquel, Pierre-Carl Michaud, Titus Gamama, and Arie Kapteyn, 2009, "On the Rise of Health Spending and Longevity," IZA Discussion paper \#4622

Gouveia, Miguel and Robert R. Strauss. 1994. "Effective Federal Individual Income Tax Functions: An Exploratory Empirical Analysis." National Tax Journal 47(2) (June): 317--39.

Gouveia, Miguel and Robert R. Strauss. 1999. "Effective Tax Functions for the U.S. Individual Income Tax: 1966--89." Proceedings of the 92nd Annual Conference on Taxation, National Tax Association: 155--65.

Grossman, Michael, 1972, "One the Concept of Health Capital and the Demand for Health," Journal of Political Economy, 80, 223-255

Hubbard, Glen R., Jonathan Skinner, and Stephen P. Zeldes. 1995. "Precautionary Saving and Social Insurance." Journal of Political Economy, 103(2) (April): 360--99.

Kopecky, Karen and Tatyana Koreshkova, 2009, "The Impact of Medical and Nursing Home Expenses and Social Insurance Policies on Saving and Inequality," mimeo

McGrattan, Ellen R. and Edward C. Prescott. 2003. "Average Debt and Equity Returns: Puzzling?" American Economic Review Papers and Proceedings. 93(2) (May): 392--397.

Mincer, J., 1974, Schooling, Experience and Earnings, Columbia University Press, New York, 1974.

Moffitt, Robert. 2002. "Documentation for Moffitt Welfare Benefits File.” Manuscript (February 22), Johns Hopkins Univ. http://www.econ.jhu.edu/people/moffitt/ben_doc.pdf. 
Murphy, Kevin M. and Topel, Robert H. (2006). "The Value of Health and Longevity," Journal of Political Economy 114 (5):871-904.

Palumbo, Michael G. 1999. "Uncertain Medical Expenses and Precautionary Saving Near the End of the Life Cycle." Review of Economic Studies 66(2): 395-421.

Scholz, John Karl, and Ananth Seshadri. 2010. "Health and Wealth in a Lifecycle Model." Mimeo, University of Wisconsin - Madison

Scholz, John Karl, Ananth Seshadri, and Surachai Khitatrakun. 2006. "Are Americans Saving 'Optimally' for Retirement?" Journal of Political Economy. August, 607-643.

Smith, James P., "Consequences and Predictors of New Health Events," in D. Wise (ed.) Advances in the Economics of Aging. University of Chicago Press, 2005.

Yogo, Motohiro, 2009, "Portfolio Choice in Retirement: Health Risk and the Demand for Annuities, Housing, and Risky Assets," mimeo 


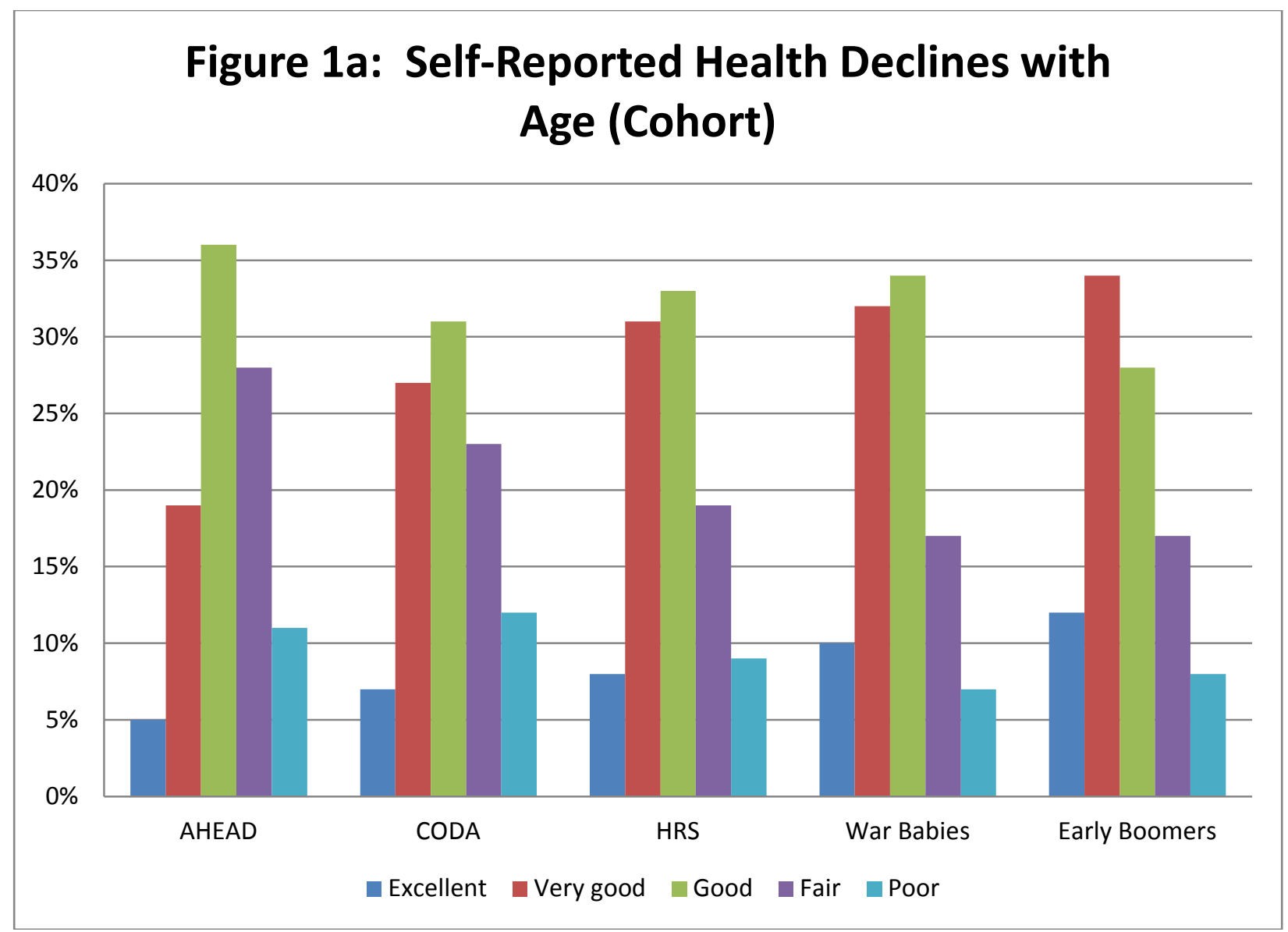




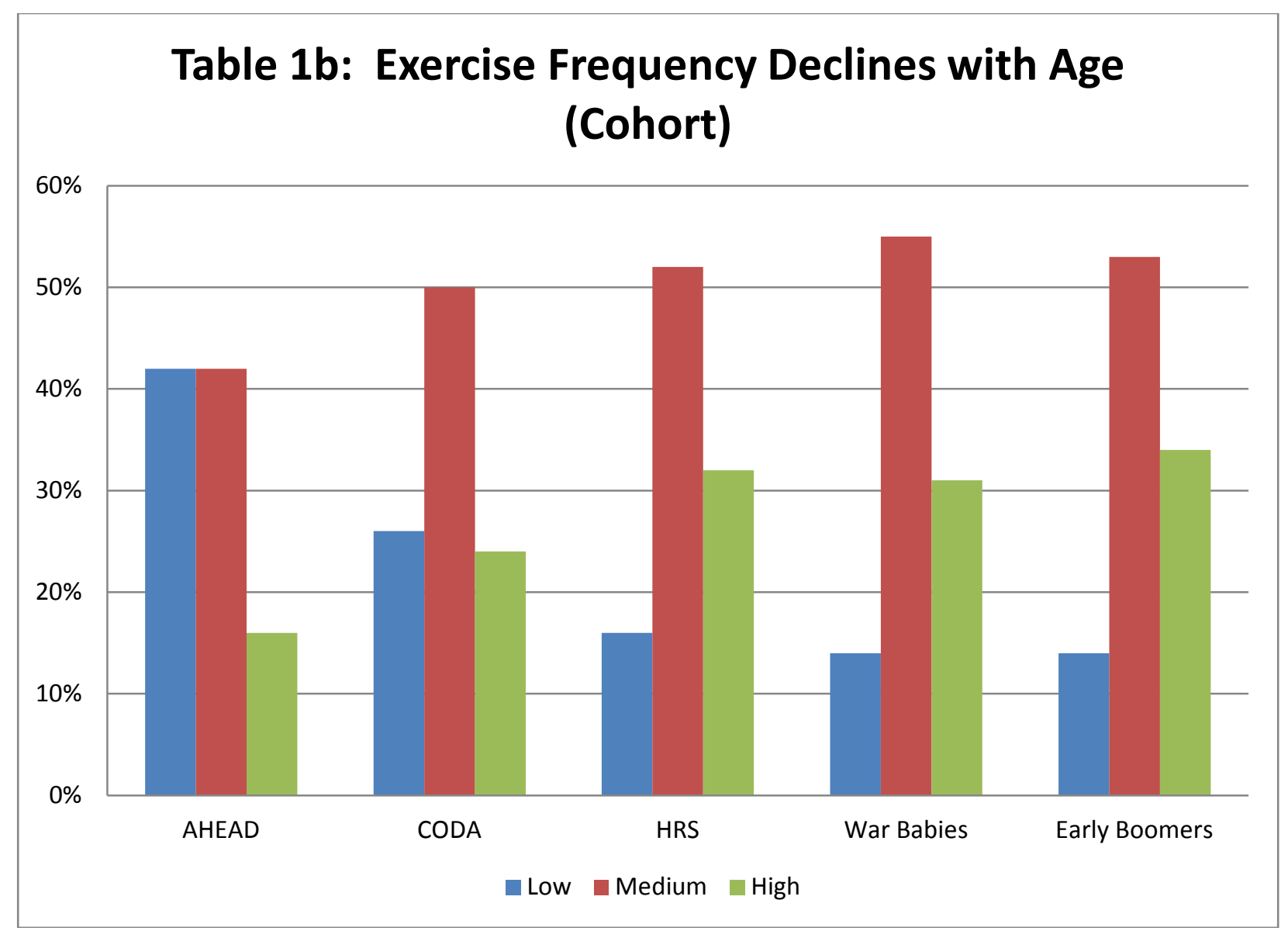




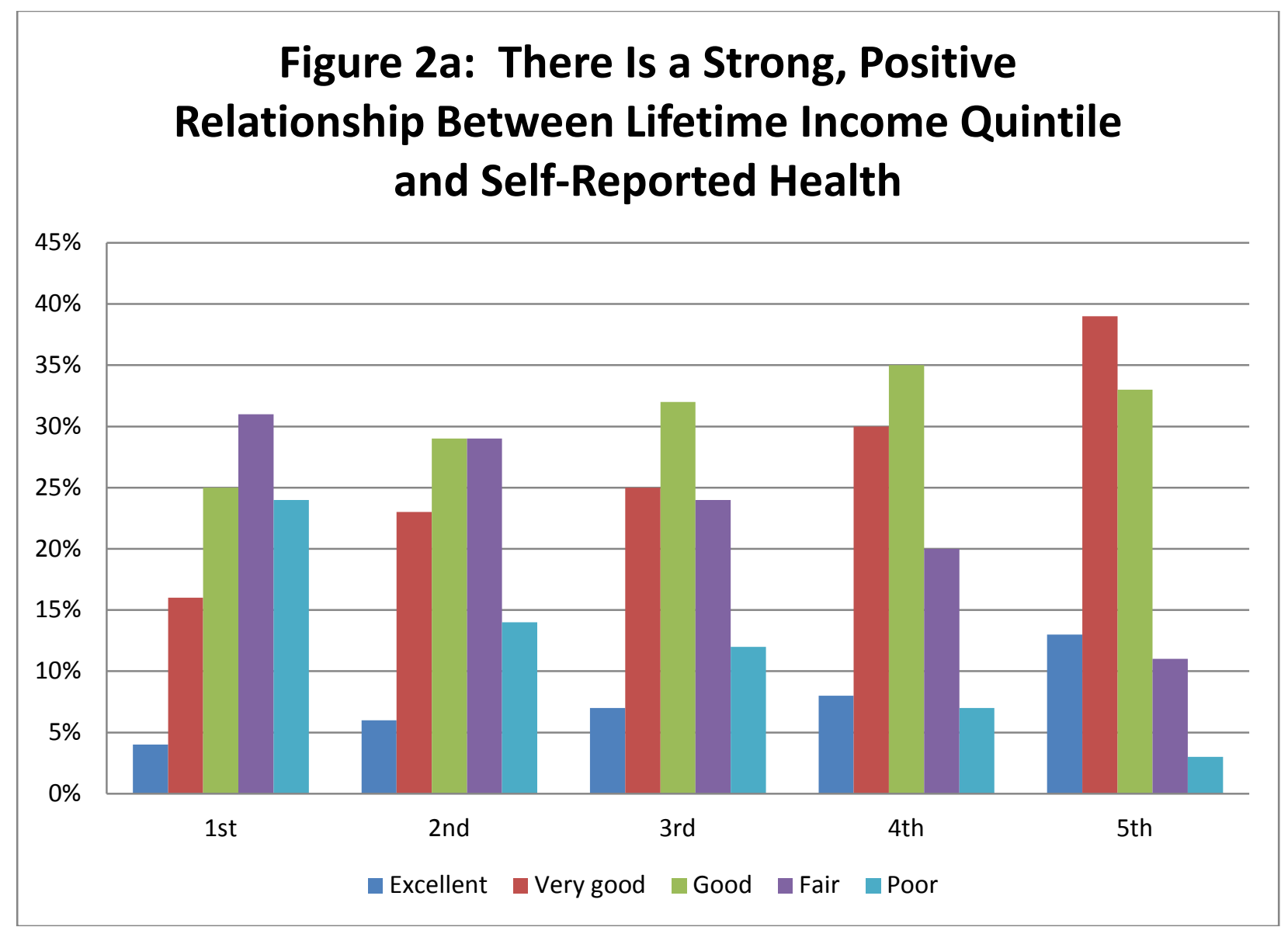




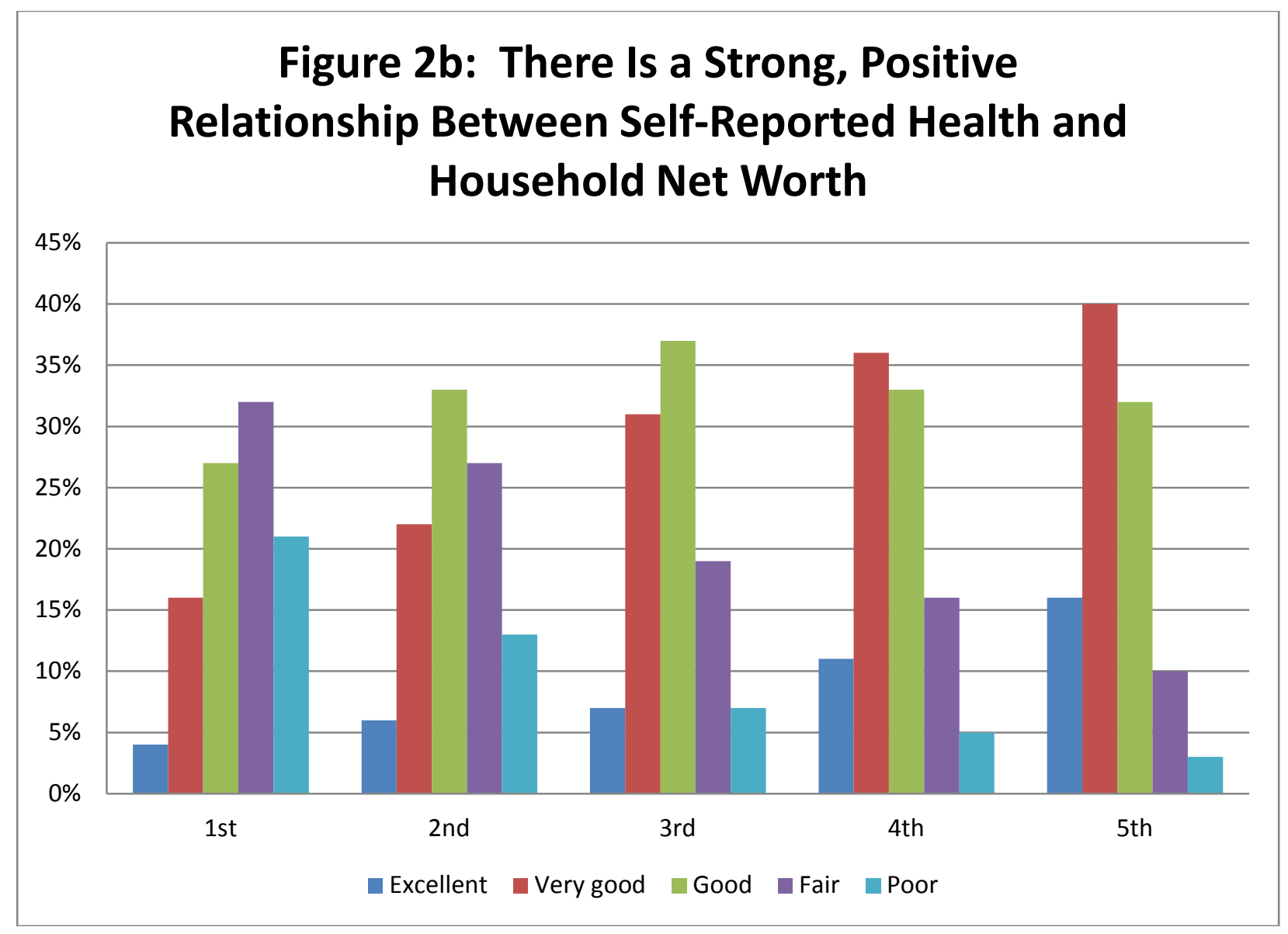




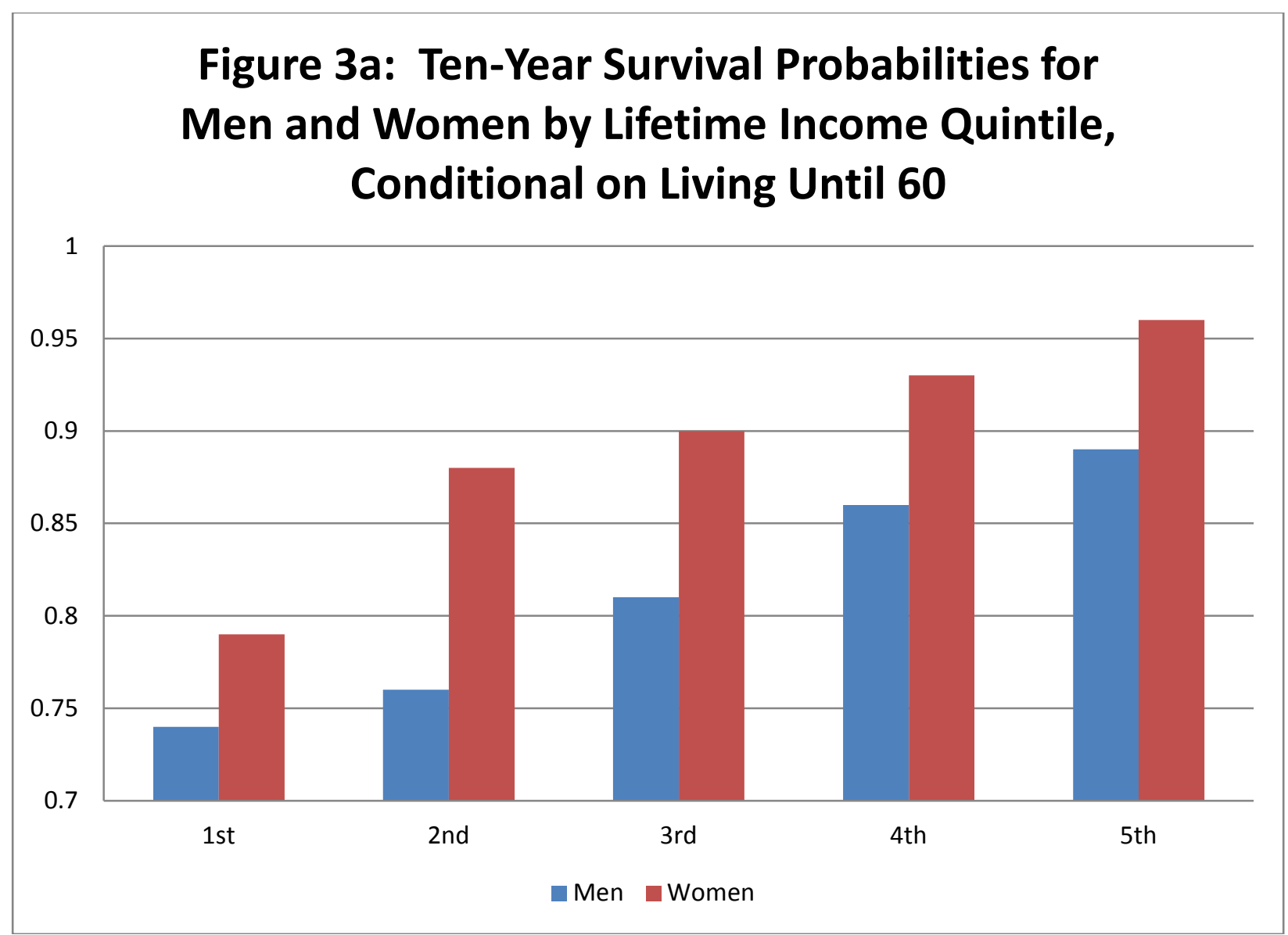




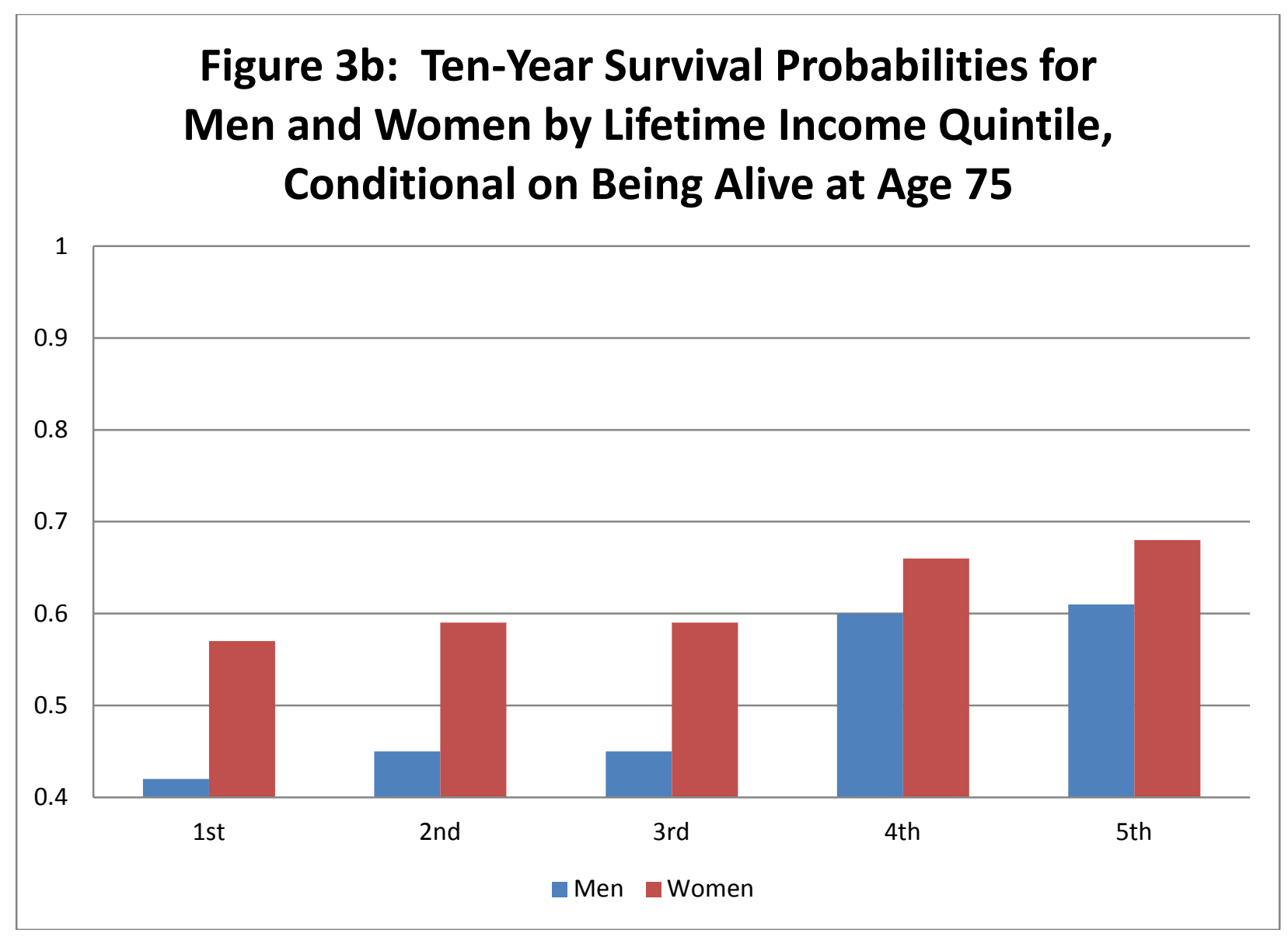

